\title{
Ascites and Encapsulating Peritonitis in Endometriosis: a Systematic Review with a Case Report
}

\section{Endometriose com ascite e peritonite encapsulante: uma revisão sistemática com descrição de um caso clínico}

\author{
Thais Fontes de Magalhães ${ }^{1}$ Kathiane Lustosa Augusto ${ }^{1,2}$ Livia Ponte Mota ${ }^{3}$ Arthur Ribeiro da Costa ${ }^{3}$ \\ Rainardo Antonio Puster ${ }^{3}$ Leonardo Robson Pinheiro Sobreira Bezerra ${ }^{1}$
}

${ }^{1}$ Department of Gynecology, Universidade Federal do Ceará, Fortaleza, CE, Brazil

2 Department of Gynecology, Universidade de Fortaleza, Fortaleza, CE, Brazil

${ }^{3}$ Department of Internal Medicine, Universidade Federal do Ceará, Fortaleza, Brazil

Rev Bras Ginecol Obstet 2018;40:147-155.

\begin{abstract}
Address for correspondence Thais Fontes de Magalhães, MD, Departmento de Ginecologia, Universidade Federal do Ceara, Rua Alexandre Barauna 949, Fortaleza, CE, 60430-160, Brazil (e-mail: thaisfdemagalhaes@gmail.com).
\end{abstract}

\begin{abstract}
Keywords

- endometriosis

- ascites

- peritonitis

- systematic review

- treatment
\end{abstract}

\section{Resumo}

Endometriosis can have several different presentations, including overt ascites and peritonitis; increased awareness can improve diagnostic accuracy and patient outcomes. We aim to provide a systematic review and report a case of endometriosis with this unusual clinical presentation. The PubMed/MEDLINE database was systematically reviewed until October 2016. Women with histologically-proven endometriosis presenting with clinically significant ascites and/or frozen abdomen and/or encapsulating peritonitis were included; those with potentially confounding conditions were excluded. Our search yielded 37 articles describing 42 women, all of reproductive age. Ascites was mostly hemorrhagic, recurrent and not predicted by cancer antigen 125 (CA-125) levels. In turn, dysmenorrhea, dyspareunia and infertility were not consistently reported. The treatment choices and outcomes were different across the studies, and are described in detail. Endometriosis should be a differential diagnosis of massive hemorrhagic ascites in women of reproductive age.

A endometriose pode ter várias apresentações, incluindo ascite e peritonite, que são apresentações incomuns. $\mathrm{O}$ aumento da conscientização sobre essa doença pode melhorar a precisão diagnóstica e os resultados das pacientes. Nosso objetivo é fornecer uma revisão sistemática e relatar um caso de endometriose com esta apresentação clínica incomum. $\mathrm{O}$ banco de dados PubMed/MEDLINE foi revisado sistematicamente até outubro de 2016. Foram incluídas mulheres com endometriose demonstrada histologicamente, com presença de ascite clinicamente significativa e/ou abdômen congelado e/ou peritonite encapsulante; foram excluídas aquelas com comorbidades que pudessem provocar confusão. A pesquisa selecionou 37 artigos que descrevem 42 mulheres, todas em idade reprodutiva. A ascite foi principalmente hemorrágica, recorrente, e não indicada pelos níveis de antígeno associado ao câncer 125 (AC-125). Por sua vez, a dismenorreia, a dispareunia e a infertilidade não foram relatadas de forma consistente. As escolhas e os resultados do tratamento foram diferentes entre os estudos, e são descritos em detalhes. A endometriose deveria ser um diagnóstico diferencial de ascite hemorrágica maciça em mulheres em idade reprodutiva. received

September 12, 2017

accepted

December 20, 2017

published online

March 19, 2018
DOI https://doi.org/

10.1055/s-0038-1626700. ISSN 0100-7203.
Copyright $\odot 2018$ by Thieme Revinter

Publicações Ltda, Rio de Janeiro, Brazil
License terms

(ㄷ) (i) $\ominus$ (5) 


\section{Introduction}

Endometriosis is defined as the presence of endometrial tissue outside of the uterine cavity, which, like the eutopic endometrium, responds to hormonal stimuli. ${ }^{1}$ Although the symptoms related to endometriosis may be associated with the location of the implant, they are unrelated to the extent of the disease, and a variety of clinical presentations have been described, including the presence of a small amount of peritoneal fluid. ${ }^{2}$ It is very rare, however, for endometriosis to present as overt ascites, and the presence of such a condition should prompt the investigation of differential diagnoses, such as malignancy. ${ }^{3}$ The occurrence of encapsulating peritonitis, described as the encapsulation of bowel loops by a thick fibrinogenous case, is even rarer, with only five cases previously described in the medical literature. ${ }^{3-8}$

Women who present with ascites due to endometriosis often undergo multiple diagnostic procedures, including invasive ones, before the underlying cause for ascites is found. ${ }^{9}$ This results in increased patient risks and health care costs. ${ }^{10}$ General and emergency physicians, as well as gynecologists, should be aware of endometriosis as a potential cause of ascites and encapsulating peritonitis to promptly diagnose it.

With this in mind, this study aims to bring attention to the case of a woman presenting with encapsulating peritonitis and multiple episodes of massive ascites. We also provide a systematic review of the literature regarding the association between histologically-proven endometriosis and clinicallysignificant ascites, frozen abdomen or encapsulating peritonitis, including detailed characteristics of their presentations, proposed treatments and outcomes.

\section{Methods}

For this systematic review, we used the protocol outlined by the Preferred Reporting Items for Systematic Reviews and Meta-analyses (PRISMA) Statement (-Fig. 1). The electronic PubMed database was searched until October 2016 using the detailed strategy described in - Table 1 . The case of a woman with endometriosis, recurrent ascites and encapsulating peritonitis observed at our clinic is also described. The review has been approved by the Ethics in Research Committee under the protocol number 006.01.2017.

\section{Eligibility Criteria}

Original articles, clinical trials, case series and case reports of women of any age with histologically-proven endometriosis, presenting with clinically significant ascites and/or frozen abdomen and/or encapsulating peritonitis, published in English, Portuguese, French or Spanish, were eligible for this review.

Because other causes that may occur concurrently with endometriosis can cause the clinical presentations described, we excluded papers describing patients with: cancer of the ovaries, appendix or peritoneum, or other intraabdominal cancers; tuberculosis; ovarian hyperstimulation syndrome; ovarian induction or other known causes of massive ascites; and ascites beginning in the immediate or early post-operative period of exploratory laparotomy/laparoscopy. Animal studies; articles published in languages other than the aforementioned ones; and reviews of the literature were also excluded.

\section{Study Selection}

The references retrieved were independently screened by two investigators, KA and TM. Initially, the screening was made by title and abstract; then, the full-text versions of the selected papers were obtained, and each article was reviewed for final inclusion. If a consensus could not be reached, another author (LB) made the final decision regarding inclusion.

\section{Data Extraction}

A standardized table was used for data extraction on each selected paper, and information regarding the first author, the country of origin, the journal and year of publication, the study type, patient/sample age, patient origin or ethnicity, the clinical presentation, the proposed treatment, and the outcome were included. The characteristics of the ascitic fluid and data regarding the presence or absence of encapsulating peritonitis were also recorded. Data extraction was performed independently by two investigators (KA and TM).

\section{Case Description}

A 28-year-old woman presented to the internal medicine clinic at our institution with wasting syndrome, increased abdominal girth, progressive shortness of breath, dark stools and decreased appetite. She also complained of progressive abdominal and thoracic pain during menses, as well as cyclic dyspareunia that had started five years before. She denied infertility or any other chronic medical conditions. Her cancer antigen 125 (CA-125) values were 107.8 and 889.6 on two measurements performed when she was an internal medicine inpatient.

Abdominal ultrasound and contrasted computed tomography (CT) studies showed loculated, cystic-like ascites producing a mass effect. A paracentesis procedure revealed a thick, hemorrhagic fluid with low albumin, high cellularity and large concentration of red blood cells (-Fig. 2 ). The fluid analysis was negative for bacterial growth or cancer cells. During the diagnostic laparoscopy, multiple adhesions and peritoneal lesions were noticed, and the patient's abdomen was described as "frozen," due to the presence of encapsulating peritonitis, which did not enable the separation of the peritoneal layers and the confection of the pneumoperitoneum. Eight liters of fluid were removed. Histopathology of a peritoneal biopsy taken at this time described chronic peritonitis and scarce hemosiderin deposits.

One month after the initial imaging exam, another contrasted abdominal CT suggested the presence of sclerosing encapsulating peritonitis ( - Fig. 3). At this point, the patient was referred to our gynecology clinic due to suspected endometriosis. This diagnosis was further suggested by a gynecological exam, ultrasound mapping and a magnetic resonance imaging (MRI) scan, which showed evidence of fibrosis in the anterior vaginal fornix, multiple peritoneal 


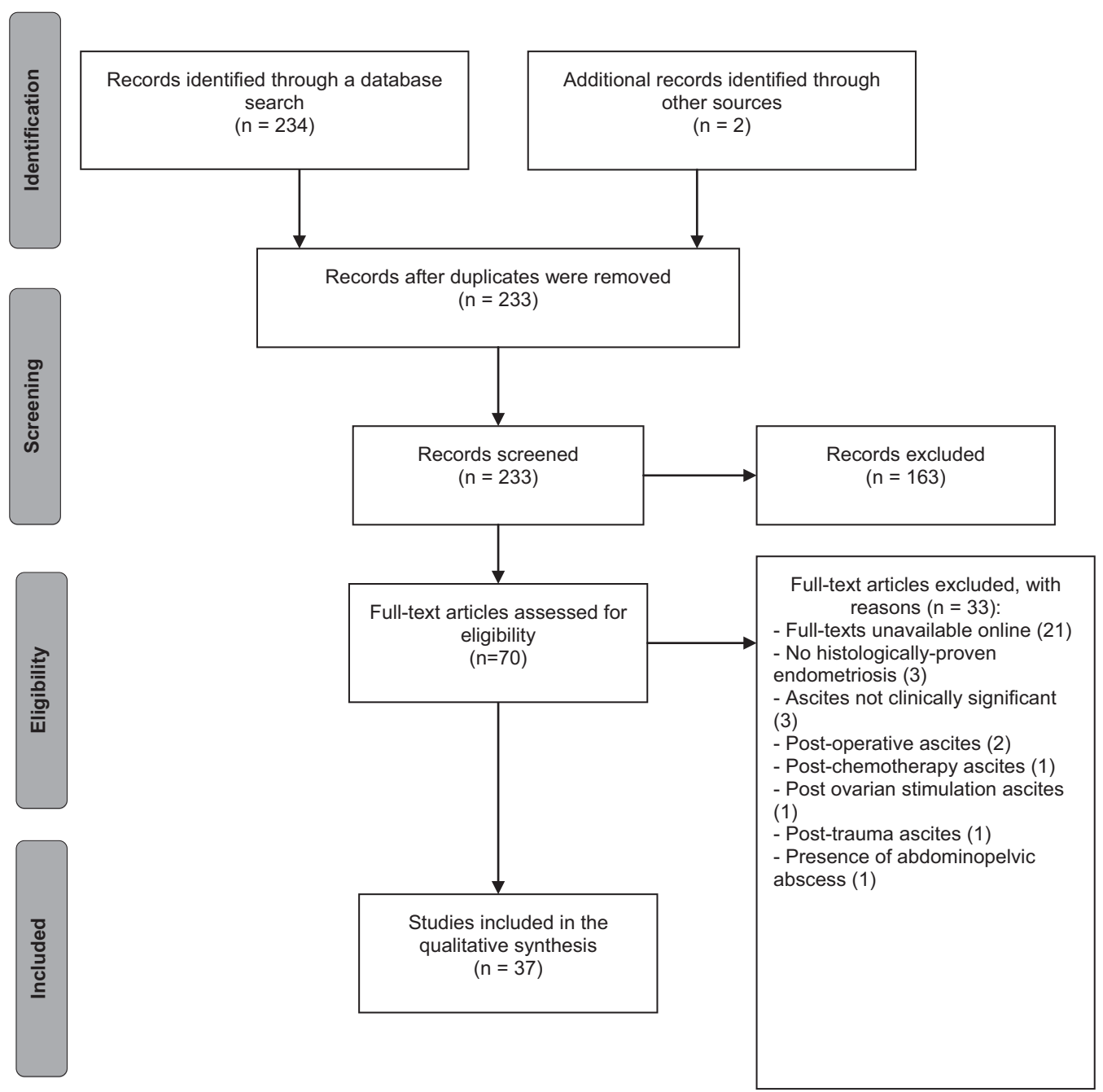

Fig. 1 Flow diagram describing the steps in the study selection for inclusion in this systematic review.

nodules, and apparently hemorrhagic bilateral ovarian cysts. The chest CT and the colonoscopy at that time were normal.

A new laparoscopy was performed, and a biopsy confirmed the diagnosis of endometriosis. Due to peritoneal adhesions, it was not possible to access the pelvic and abdominal organs. This patient was treated with goserelin acetate, with good clinical response. At the six-month followup, she was asymptomatic and had regained a considerable amount of weight.

Table 1 Detailed search strategy used in the advanced tool of the PubMed/MEDLINE database

\begin{tabular}{|l|l|}
\hline Search & Keywords \\
\hline$\# 1$ & $\begin{array}{l}\text { peritoneal fibrosis OR encapsulating } \\
\text { peritoneal sclerosis OR sclerosing } \\
\text { encapsulating peritonitis } \\
\text { OR abdominal cocoon OR frozen } \\
\text { abdomen OR ascites }\end{array}$ \\
\hline$\# 2$ & $\begin{array}{l}\text { endometriosis OR endometrioma OR } \\
\text { endometriotic OR hemosiderophage }\end{array}$ \\
\hline Final search & $\# 1$ AND \#2 \\
\hline
\end{tabular}

\section{Results}

\section{Study Characteristics}

Our systematic review yielded 37 articles describing 42 patients with clinically significant ascites, encapsulating peritonitis, or frozen abdomen. One author had a series of three cases, while another had a series of four cases; all of the remaining articles reported only one case each. ${ }^{11,12}$ The publication dates ranged from 1978 to 2016.

\section{Patient Characteristics and Clinical Presentation}

The ages of the women who fulfilled the eligibility criteria ranged from 20 years to 47 years. ${ }^{13,14}$

A total of 8 women in the included articles were described as "black"; 3, as "African-American"; and 2, as "Afro-Caribbean."12,13,15-22 One patient described herself as "African;" another patient, as "caucasian;" a third one, as "Hispanic;" and another one, as "negro."23-26 Seven studies did not describe ethnicity, but reported that the patients were Nigerian $(n=3)$, Malay $(n=2)$, Brazilian $(n=1)$ or Japanese $(n=1) .^{3,6,8,27-30}$ Ethnicity or origin was not described at all for the remaining 16 patients. $5,7,11,14,31-42$ 


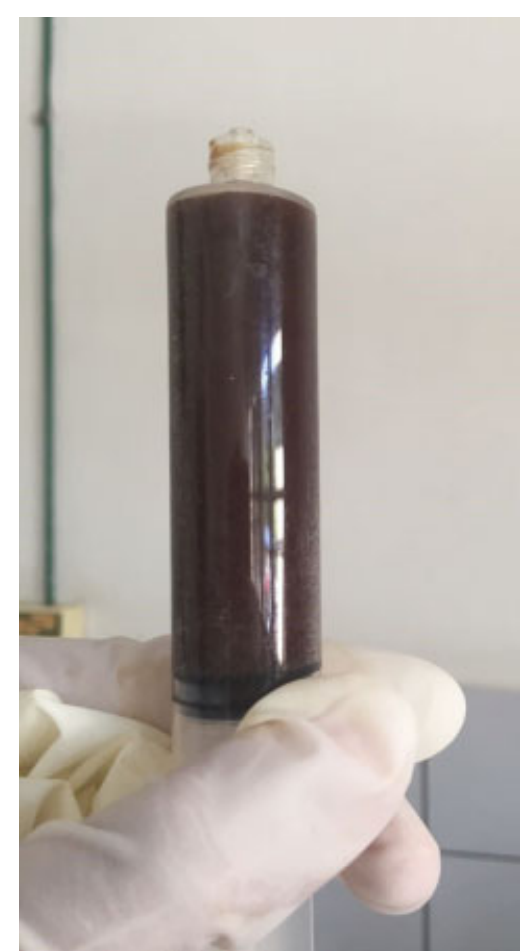

Fig. 2 Thick, hemorrhagic ascitic fluid sample.

The ascites was of acute onset in 8 women, and gradual in 24 patients (-Supplementary Material 1). The type of onset was not reported in six cases.

In most patients, the ascites was described as "hemorrhagic" and "recurrent," but descriptions such as "yellow," "clear yellow," "brownish green" and "loculated" were also observed. ${ }^{3,6,8,13,25,32,33}$ Ascites was present but not characterized in five cases. ${ }^{5,14,15,19,34}$

The volume of ascitic fluid was not shown in some studies, but there are reports of $4.2 \mathrm{~L}, 4.8 \mathrm{~L}, 5.0 \mathrm{~L}$ and $7 \mathrm{~L}{ }^{13,29,36,41}$ There was associated pleural effusion in eleven patients. $3,12,18,19,21,23,32,33,40$
Liver involvement by endometriosis was cited in four cases, including one with cysts and another with non-specified focal lesions. 3,34

Twenty-two articles reported CA-125 levels. Normal levels were observed in six patients. The biomarker was elevated $(>35 \mathrm{U} / \mathrm{mL}$ ) in 14 patients, ranging from $49 \mathrm{U} / \mathrm{mL}$ to $>5,000 \mathrm{U} / \mathrm{mL}$. One case had normal CA-125 levels at first, but they became elevated $(455 \mathrm{U} / \mathrm{mL})$ after ascites recurrence. $^{12}$

The most common main clinical presentation was abdominal distension, which was sometimes accompanied by other symptoms such as abdominal pain, abdominal tenderness, abdominal mass, shortness of breath, signs of hypovolemia, weight loss, nausea or vomiting, asthenia, malaise, cachexia or loss of appetite. In 25 of the 42 women described, at least one symptom of the classic dysmenorrhea, dyspareunia and infertility triad was reported. Of these, dysmenorrhea was the most common, and it was reported in 20 women. $8,11-13,15,16,18,20,22-24,27,30-32,36,38-41$ Infertility was reported in 11 patients. ${ }^{11,18,19,22-24,29-31,40,41}$ Dyspareunia was reported in 4 patients. ${ }^{15,22,24,36}$ All three symptoms were present in two studies. ${ }^{22,24}$ However, in 15 articles (describing 17 patients), the presence or absence of dysmenorrhea was not mentioned at all. ${ }^{5-7,12,14,19,21,25,26,28,29,33-35,37} \mathrm{~A}$ total of 33 studies (with 38 patients) were regarding the presence or absence of dyspareunia, $3,5-8,11-14,16-21,25-35,37-42$ and 25 studies (with 28 patients) were regarding the presence or absence of infertility. ${ }^{3,5-8,11-17,21,25-28,32-39}$ Fifteen articles did not mention if any of these three symptoms were present or absent in the cases they reported. ${ }^{5-7,12,14,21,25,26,28,33-35,37}$

Besides our patient, only five cases of encapsulating peritonitis due to endometriosis have been described in the medical literature. ${ }^{3,5-8}$

\section{Treatments Used and Outcomes}

The treatment choices for the patients included in this review involved hormonal therapies, surgery, anti-inflammatory drugs (steroidal or non-steroidal) or a combination of
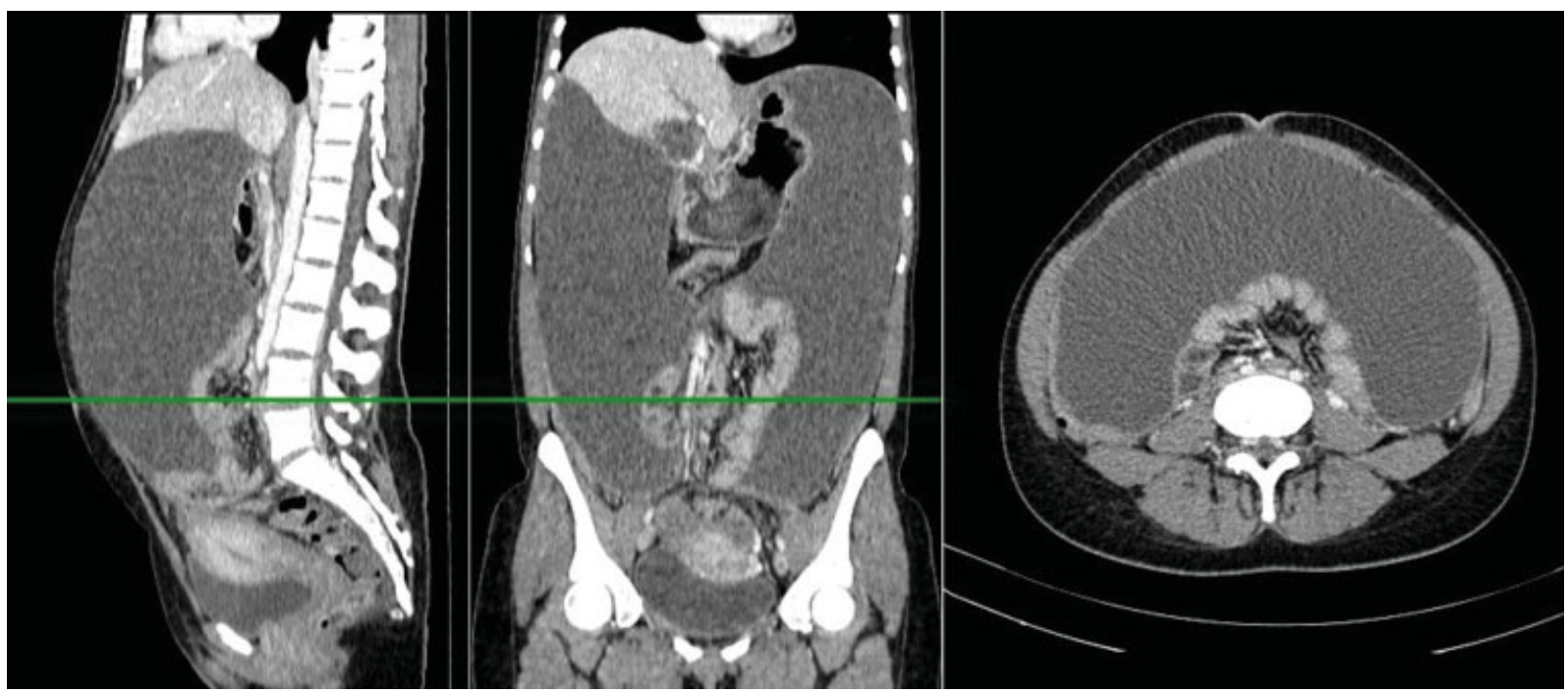

Fig. 3 Contrasted computed tomography (CT) showing massive ascites, centrally encased bowels, and thickened peritoneum. 
Table 2 Treatment choices and respective outcomes in each study. Outcomes written as described in each article

\begin{tabular}{|c|c|c|}
\hline & Treatment for ascites & Outcome \\
\hline \multirow[t]{2}{*}{ Dun et al, $2016^{29}$} & Leuprolide + oral norethindrone & Ascites persisted \\
\hline & $\begin{array}{l}\text { Laparoscopic evacuation of ascites and } \\
\text { excision of endometriosis }\end{array}$ & No recurrence (6-month follow-up) \\
\hline \multirow[t]{2}{*}{ Hasdemir et al, $2015^{40}$} & Leuprorelin acetate for 6 months & $\begin{array}{l}\text { Resolution of symptoms until } 2 \text { months } \\
\text { after cessation }\end{array}$ \\
\hline & Dienogest & $\begin{array}{l}\text { Resolution of symptoms (3-month follow- } \\
\text { up) }\end{array}$ \\
\hline \multirow[t]{3}{*}{ Hinduja et al, $2016^{42}$} & Leuprolide 3.75 mg monthly & Recurrence after 6 months \\
\hline & $\mathrm{TAH}+\mathrm{BSO}$ & $\begin{array}{l}\text { Ascitic fluid leakage through vaginal suture } \\
\text { line (10 days after the operation) }\end{array}$ \\
\hline & $\begin{array}{l}\text { Short-acting GnRH agonist + oral danazol } \\
\text { followed by } \mathrm{GnRH} \text { only }\end{array}$ & No recurrence (1-year follow-up) \\
\hline \multirow[t]{4}{*}{ Setubal et al, $2015^{24}$} & Continuous OCP for 3 months & Ascites persisted \\
\hline & $\begin{array}{l}\text { GnRH agonist, then laparoscopic excision } \\
\text { of lesions followed by GnRH agonist }\end{array}$ & Minimal ascites \\
\hline & Underwent IVF protocol & Minimal ascites \\
\hline & OCP & Symptom-free \\
\hline Appleby et al, $2014^{28}$ & GnRH antagonist & No recurrence (6-month follow-up) \\
\hline \multirow[t]{2}{*}{ Asano et al, $2014^{30}$} & GnRH agonist & Ascites recurred \\
\hline & Oral dienogest & No recurrence (1-year follow-up) \\
\hline \multirow[t]{2}{*}{ Bignall et al, $2014^{22}$} & GnRH agonists & Ascites recurred \\
\hline & $\begin{array}{l}\text { GnRH agonists + tibolone + NSAIDs + } \\
\text { pregabalin }\end{array}$ & Symptoms well-controlled \\
\hline Cosma et al, $2014^{41}$ & Laparoscopic excision of lesions & Modest recurrence $(250 \mathrm{~mL})$ after 42 days \\
\hline \multirow[t]{3}{*}{ Shabeerali et al, $2012^{11}$} & CASE 1: GnRH analogue & No recurrence (6-month follow-up) \\
\hline & $\begin{array}{l}\text { CASE 2: Subtotal abdominal } \\
\text { hysterectomy }+ \text { BSO }\end{array}$ & No recurrence (1-year follow-up) \\
\hline & $\begin{array}{l}\text { CASE 3: GnRH analogues for } 1 \text { year; then, } \\
\text { TAH + BSO }\end{array}$ & $\begin{array}{l}\text { Partial response; then, relatively asympto- } \\
\text { matic at } 1 \text {-year follow-up }\end{array}$ \\
\hline Ferrero and Remorgida, $2011^{36}$ & Norethindrone acetate (25 mg daily) & No recurrence (1-year follow-up) \\
\hline Ignacio et al, $2010^{18}$ & GnRH analogue & No recurrence (8-month follow-up) \\
\hline Lin et al, $2010^{37}$ & $\begin{array}{l}\text { Laparoscopic electrocauterization of } \\
\text { lesions }\end{array}$ & Condition stabilized \\
\hline Suchetha et al, $2010^{7}$ & GnRH analogues for 1 year & Good response \\
\hline Park et al, $2009^{39}$ & $\begin{array}{l}\text { Laparoscopic excision of endometrioma } \\
+ \text { GnRH agonist for } 6 \text { months }+ \text { tibolone }\end{array}$ & No recurrence (1-year follow-up) \\
\hline Sait, $2008^{38}$ & $\begin{array}{l}\text { Bilateral ovarian cystectomies }+\mathrm{GnRH} \\
\text { analogue for } 6 \text { months followed by OCP }\end{array}$ & No recurrence (2-year follow-up) \\
\hline Santos et al, $2007^{6}$ & Laparoscopy + laparotomy & NR. Patient died after 5 months \\
\hline Palayekar et al, $2007^{20}$ & $\mathrm{TAH}+\mathrm{BSO}$ & No recurrence (1-year follow-up) \\
\hline \multirow[t]{4}{*}{ Fortier et al, $2005^{23}$} & $\begin{array}{l}\text { Ovarian cystectomy }+ \text { GnRH analogue for } \\
6 \text { months }+ \text { laparoscopic excision of } \\
\text { lesions }+ \text { oral progesterone for } 6 \text { months }\end{array}$ & Two recurrences \\
\hline & $\begin{array}{l}\text { Ceased treatment and started clomiphene } \\
\text { due to pregnancy desire }\end{array}$ & Ascites recurrence \\
\hline & GnRH for 2 months & Ascites recurrence \\
\hline & GnRH for 6 months & Ascites recurrence \\
\hline Mohd Noor et al, $2004^{8}$ & Laparotomy + excision of lesions & No recurrence (4-week follow-up) \\
\hline Zeppa et al, $2004^{35}$ & NR & NR \\
\hline
\end{tabular}


152 Ascites and Encapsulating Peritonitis in Endometriosis Magalhães et al.

Table 2 (Continued)

\begin{tabular}{|c|c|c|}
\hline & Treatment for ascites & Outcome \\
\hline Cheong and Lim, $2003^{3}$ & NR & NR \\
\hline Jeanes et al, $2002^{34}$ & $\begin{array}{l}\text { Double hysterectomy }+ \text { left oophorect- } \\
\text { omy followed by estradiol for } 6 \text { months } \\
\text { followed by goserelin }\end{array}$ & No recurrence (3-year follow-up) \\
\hline \multirow[t]{2}{*}{ Moffatt and Mitchell, $2002^{19}$} & Leuprolide + premarin & Recurrence after 4 weeks \\
\hline & $\mathrm{TAH}+\mathrm{BSO}+$ leuprolide & No recurrence (9-month follow-up) \\
\hline Bhojawala et al, $2000^{17}$ & $\mathrm{TAH}+\mathrm{RSO}$ & No recurrence (6-week follow-up) \\
\hline Samora-Mata and Feste, $1999^{25}$ & $\mathrm{TAH}+\mathrm{RSO}$ & NR \\
\hline \multirow[t]{4}{*}{ Myneyyirci-Delale et al, $1998^{12}$} & $\begin{array}{l}\text { Laparoscopic excision of lesions followed } \\
\text { by GnRH agonist for } 6 \text { months; then, } \\
\text { excision of new ovarian cyst }+ \text { danazol } \\
\text { daily for } 6 \text { months followed by norethin- } \\
\text { drone acetate }\end{array}$ & $\begin{array}{l}\text { Recurrence after } 1 \text { year; then, no recur- } \\
\text { rence (3-year follow-up) }\end{array}$ \\
\hline & $\begin{array}{l}\text { Laparotomy + monthly depo provera } \\
\text { injections; then, TAH + BSO }\end{array}$ & $\begin{array}{l}\text { Recurrence after } 3 \text { years; then, no recur- } \\
\text { rence (6-month follow-up) }\end{array}$ \\
\hline & $\begin{array}{l}\text { Appendectomy and left ovarian wedge } \\
\text { resection + lupron }\end{array}$ & No recurrence \\
\hline & $\begin{array}{l}\text { Lysis of adhesions }+ \text { LSO followed by } \\
\text { lupron followed by norethindrone acetate }\end{array}$ & NR \\
\hline Frigerio et al, $1997^{5}$ & $\begin{array}{l}\mathrm{TAH}+\mathrm{BSO}+\text { appendectomy }+ \text { omen- } \\
\text { tectomy }\end{array}$ & No recurrence (3-year follow-up) \\
\hline Mejia et al, $1997^{16}$ & Laparotomy & No recurrence (15-month follow-up) \\
\hline \multirow[t]{3}{*}{ Flanagan and Barnes, $1996^{21}$} & Laparotomy + GnRH agonist for 6 months & Recurrence (twice in 1 year) \\
\hline & Prednisolone 30 mg daily & Recurrence \\
\hline & Leuprorelin for 5 months & Recurrence \\
\hline Myers et al, $1995^{33}$ & $\mathrm{TAH}+\mathrm{BSO}+$ lysis of adhesions & No recurrence (8-month follow-up) \\
\hline \multirow[t]{2}{*}{ Jose et al, $1994^{32}$} & LSO & Recurrence after 1 year \\
\hline & Laparotomy + danazol & NR \\
\hline Schlueter an McClennan, $1994^{13}$ & Leuprolide acetate monthly & No recurrence (3-month follow-up) \\
\hline \multirow[t]{4}{*}{ Williams and Wagaman, $1991^{15}$} & Medroxyprogesterone acetate & Recurrence after 1 month \\
\hline & Depot lupron for 3 months & Some ascites \\
\hline & $\mathrm{TAH}+\mathrm{BSO}$ & Recurrence after 3 months \\
\hline & Tenckhoff catheter placed for 2 weeks & No recurrence (9-month follow-up) \\
\hline $\begin{array}{l}\text { Chichareon and Wattanakitkrailert, } \\
1988^{31}\end{array}$ & $\mathrm{TAH}+\mathrm{BSO}$ & No recurrence (6-month follow-up) \\
\hline Olubuyide et al, $1988^{27}$ & Oral norethisterone & No recurrence (1-year follow-up) \\
\hline Naraynsingh et al, $1985^{26}$ & Depo provera for 6 months & No recurrence (4-year follow-up) \\
\hline Cantor et al, $1979^{14}$ & NR & NR \\
\hline
\end{tabular}

Abbreviations: BSO, bilateral salpingo-oophorectomy; GnRH, gonadotropin-releasing hormone; IVF, in vitro fertilization; LSO, left salpingooophorectomy; NR, not reported; NSAIDs, non-steroidal anti-inflammatory drugs; OCP, oral contraceptive pills; RSO, right salpingo-oophorectomy; $\mathrm{TAH}$, total abdominal hysterectomy.

them. Ascites recurrence or persistence was frequent. Three articles did not report how the patients were managed (-Table 2). ${ }^{3,14,35}$

The hormonal therapies used included long-acting gonadotropin-releasing hormone $(\mathrm{GnRH})$ agonists (namely goserelin and leuprolide), short-acting GnRH agonists, GnRH antagonists, progestational hormones (specifically dienogest, medroxyprogesterone and norethindrone), estradiol, conjugated estrogens, synthetic combined hormones (namely tibolone), steroids with antigonadotropic and antiestrogenic activity (danazol), and oral contraceptive pills (OCPs).

Other conservative treatments used were isolated prednisolone, which did not prevent ascites recurrence, and 
nonsteroidal anti-inflammatory drugs (NSAIDs) in combination with pregabalin and hormonal therapies, which were effective in controlling the symptoms.

The surgical procedures involved drainage of the ascites, excision or electrocauterization of the endometriotic lesions through laparotomy or laparoscopy, lysis of adhesions, abdominal hysterectomy, uni- or bilateral salpingo-oophorectomy, ovarian cystectomy, omentectomy, appendectomy, placement of Tenckhoff catheter and/or ovarian wedge resection.

After the initial treatment, due to the desire to achieve pregnancy, one woman underwent in vitro fertilization (IVF), with minimal ascites afterwards. ${ }^{24}$ Another patient started clomiphene, with ascites recurrence. ${ }^{23}$

A summary of the treatments used for ascites and its respective outcomes, including the time until recurrence, is shown in - Table 2.

\section{Discussion}

All patients shown in this review were of childbearing age, likely due to hormonal levels and occurrence of menses. This is, indeed, the most common age range for the presentation of endometriosis in general, which can also rarely occur in older women. ${ }^{43}$ Endometriosis most commonly affected women of African descent, but it was present in patients of multiple other ethnicities, implying that this diagnosis should not be restricted to patient origin, and must be suspected if the clinical presentation is suitable.

Fluid accumulation was most commonly progressive, but acute onset of symptoms has also been described. The reasons for such a presentation remain unclear, but can be related to the rapid accumulation of fluid and to the spontaneous rupture of a cyst. ${ }^{37}$

Endometriosis-associated ascites is rare, and encapsulating peritonitis is even less common. Since we excluded women with potentially confounding conditions, it appears that endometriosis itself is the cause of such clinical presentations. It has been hypothesized that the peritoneal irritation caused by endometriosis results in extensive fibrosis and inflammation, further optimizing the microenvironment for more secondary implants, which in turn exacerbate inflammation. In fact, this theory could also explain the high rate of recurrence of ascites due to endometriosis ( - Table 2 ), ultimately resulting in encapsulating peritonitis, which is described in our case and in four other ones.

Abdominal distension related to ascites was the most common clinical sign, but non-specific signs and symptoms such as malaise and weight loss were also described (-Supplementary Material 1). Additionally, most women had symptoms suggestive of endometriosis, but these were not always reported, bringing attention to the high level of suspicion needed to diagnose this condition. Not all women present with classic symptoms; however, in order for diagnostic accuracy to be improved, physicians in general (including emergency room physicians) need to ask about them specifically during history-taking.

Moreover, in some cases, ascitic volume was large and related to pleural effusion, resembling Meigs syndrome.
Great volumes can be caused by the rapid production of fluid, in association with the obstruction of subdiaphragmatic lymph vessels. In turn, pleural fluid may be due to the transdiaphragmatic flow of ascites through the lymphatic channels, as has been proposed by Meigs et al, ${ }^{44}$ or due to local reactive inflammation. ${ }^{38}$

The fluid was generally hemorrhagic, but could have different aspects, such as clear yellow or green-brownish color. On this matter, Bernstein proposed a mechanism by which chocolate cysts would rupture into the peritoneal cavity, leading to irritation and ascites formation; correspondingly, other explanations relate to excessive ovarian transudation, superficial endometriosis, open endometriosis lesions or angiogenesis. ${ }^{45-47}$

Part of the included studies also measured and reported serum CA-125 levels. This biomarker is known to not be accurate for the diagnosis of endometriosis in general; likewise, it was not reliable in the diagnosis of endometriosis presenting with ascites. Although no statistical comparisons were made, it is clear that the values were not intimately correlated to the characteristics of ascites. Furthermore, endometriosis caused CA-125 levels $>5,000 \mathrm{U} / \mathrm{mL}$ in one case, which commonly indicates malignancy; this further contributes to the need of including endometriosis in the list of differentials of suspected malignancies due to massive ascites.

Several treatment choices were observed in the included articles; the options were similar to the therapies available for endometriosis in general. For the specific treatment of women presenting with ascites, no specific protocol exists, and empirical data does not evidently favor one therapy over another (-Table 2).

Among the strengths of our review are the fact that only articles with histologically proven endometriosis were selected; the exclusion of patients with conditions that commonly cause ascites; and the systematic approach. It is limited, however, in that articles in only four languages were included, and in the fact that some older articles initially screened could not be included because they were not available online, even for purchase. Further research is needed to better define optimal diagnostic and therapeutic approaches in women with unusual presentations of endometriosis.

\section{Conclusion}

Clinically significant ascites, frozen abdomen and/or encapsulating peritonitis related to endometriosis are rare conditions. It can present with abdominal distension, symptoms classically related to endometriosis, and other non-specific symptoms. The clinical presentations were heterogeneous. Endometriosis should be a differential diagnosis of massive hemorrhagic ascites in women of reproductive age, but the exclusion of other potential causes, especially malignancy, is needed for the diagnosis of this condition. The treatment options include hormonal therapy, anti-inflammatory drugs and/or surgery. There are no specific protocols for the treatment of this condition. 


\section{Contributors}

Magalhaes TF, Augusto KL, Mota LP, Costa AR, Puster RA, and Bezerra LRPS contributed with the project and interpretation of data, writing of the article, critical review of the intellectual content and final approval of the version to be published.

\section{Conflicts of Interest}

The authors have no conflicts of interest to declare.

\section{References}

1 Chen P, Wang DB, Liang YM. Evaluation of estrogen in endometriosis patients: Regulation of GATA-3 in endometrial cells and effects on Th2 cytokines. J Obstet Gynaecol Res 2016;42(06): 669-677. Doi: 10.1111/jog.12957

2 Vinci G, Arkwright S, Audebourg A, et al. Correlation between the clinical parameters and tissue phenotype in patients affected by deep-infiltrating endometriosis. Reprod Sci 2016;23(09):1258-1268. Doi: 10.1177/1933719116638188

3 Cheong EC, Lim DT. Massive ascites-an uncommon presentation of endometriosis. Singapore Med J 2003;44(02):98-100

4 Obaid O, Alhalabi D, Ghonami M. Intestinal obstruction in a patient with sclerosing encapsulating peritonitis. Case Rep Surg 2017;2017:8316147

5 Frigerio L, Taccagni GL, Mariani A, Mangili G, Ferrari A. Idiopathic sclerosing peritonitis associated with florid mesothelial hyperplasia, ovarian fibromatosis, and endometriosis: a new disorder of abdominal mass. Am J Obstet Gynecol 1997;176(03):721-722. Doi: 10.1016/S0002-9378(97)70581-7

6 Santos VM, Barbosa ER Jr, Lima SH, Porto AS. Abdominal cocoon associated with endometriosis. Singapore Med J 2007;48(09): e240-e242

7 Suchetha S, Rema P, Mathew AP, Sebastian P. Endometriosis with massive hemorrhagic ascites. Indian J Cancer 2010;47(02): 224-225. Doi: 10.4103/0019-509X.63004

8 Mohd Noor NH, Zaki NM, Kaur G, Naik VR, Zakaria AZ. Abdominal cocoon in association with adenomyosis and leiomyomata of the uterus and endometriotic cyst : unusual presentation. Malays J Med Sci 2004;11(01):81-85

9 Gupta D, Hull ML, Fraser I, et al. Endometrial biomarkers for the non-invasive diagnosis of endometriosis. Cochrane Database Syst Rev 2016;4:CD012165. Doi: 10.1002/14651858.CD012165

10 Liu E, Nisenblat V, Farquhar C, et al. Urinary biomarkers for the non-invasive diagnosis of endometriosis. Cochrane Database Syst Rev 2015;(12):CD012019. Doi: 10.1002/14651858.CD012019

11 Shabeerali TU, Rajan R, Kuruvilla AP, et al. Hemorrhagic ascites: are we missing endometriosis? Indian J Gastroenterol 2012;31 (04):195-197. Doi: 10.1007/s12664-012-0221-1

12 Muneyyirci-Delale O, Neil G, Serur E, Gordon D, Maiman M, Sedlis A. Endometriosis with massive ascites. Gynecol Oncol 1998;69 (01):42-46. Doi: 10.1006/gyno.1998.4953

13 Schlueter FJ, McClennan BL. Massive ascites and pleural effusions associated with endometriosis. Abdom Imaging 1994;19(05): 475-476

14 Cantor JO, Fenoglio CM, Richart RM. A case of extensive abdominal endometriosis. Am J Obstet Gynecol 1979;134(07):846-847. Doi: 10.1016/0002-9378(79)90958-X

15 Williams RS, Wagaman R. Endometriosis associated with massive ascites and absence of pelvic peritoneum. Am J Obstet Gynecol 1991;164(1 Pt 1):45-46. Doi: 10.1016/0002-9378(91)90621-W

16 Mejia EM, Alvarez OA, Lee M. Endometriosis with massive bloody ascites. J Am Board Fam Pract 1997;10(01):59-61

17 Bhojawala J, Heller DS, Cracchiolo B, Sama J. Endometriosis presenting as bloody pleural effusion and ascites-report of a case and review of the literature. Arch Gynecol Obstet 2000; 264(01):39-41. Doi: 10.1007/PL00007484

18 Ignacio MM, Joseph N, Hélder F, Mamourou K, Arnaud W. Massive ascites, pleural effusion, and diaphragmatic implants in a patient with endometriosis. Eur J Obstet Gynecol Reprod Biol 2010;149 (01):117-118. Doi: 10.1016/j.ejogrb.2009.10.017

19 Moffatt SD, Mitchell JD. Massive pleural endometriosis. Eur J Cardiothorac Surg 2002;22(02):321-323. Doi: 10.1016/S10107940(02)00277-4

20 Palayekar M, Jenci J, Carlson JA Jr. Recurrent hemorrhagic ascites: a rare presentation of endometriosis. Obstet Gynecol 2007;110(2 Pt 2):521-522

21 Flanagan KL, Barnes NC. Pleural fluid accumulation due to intraabdominal endometriosis: a case report and review of the literature. Thorax 1996;51(10):1062-1063. Doi: 10.1136/thx.51.10.1062

22 Bignall J, Arambage K, Vimplis S. Endometriosis: a rare and interesting cause of recurrent haemorrhagic ascites. BMJ Case Rep 2014;2014:bcr2013010052. Doi: 10.1136/bcr-2013-010052

23 Fortier D, Dedecker F, Gabriele M, Graesslin O, Barau G. [Endometriosis with ascites and pleural effusion: a case report]. Gynecol Obstet Fertil 2005;33(7-8):508-510. Doi: 10.1016/j.gyobfe.2005.05.014

24 Setubal A, Sidiropoulou Z, Soares S, Barbosa C. Endometriosis and ascites: a strategy to achieve pregnancy. J Minim Invasive Gynecol 2015;22(06):1104-1108. Doi: 10.1016/j.jmig.2015.05.013

25 Samora-Mata J, Feste JR. Endometriosis ascites: a case report. JSLS 1999;3(03):229-231

26 Naraynsingh V, Raju GC, Ratan P, Wong J. Massive ascites due to omental endometriosis. Postgrad Med J 1985;61(716):539-540. Doi: $10.1136 /$ pgmj.61.716.53

27 Olubuyide IO, Adebajo AO, Adeleye JA, Solanke TF. Massive ascites associated with endometriosis in a Nigerian African. Int J Gynaecol Obstet 1988;27(03):439-441. Doi: 10.1016/0020-7292(88) 90127-0

28 Appleby R, Saroya H, Postgate A, Meer Z. A young woman with abdominal distension. BMJ Case Rep 2014;2014:bcr2014203726. Doi: 10.1136/bcr-2014-203726

29 Dun EC, Wong S, Lakhi NA, Nehzat CH. Recurrent massive ascites due to mossy endometriosis. Fertil Steril 2016;106(06):e14. Doi: 10.1016/j.fertnstert.2016.07.1119

30 Asano R, Nakazawa T, Hirahara F, Sakakibara H. Dienogest was effective in treating hemorrhagic ascites caused by endometriosis: a case report. J Minim Invasive Gynecol 2014;21(06):1110-1112. Doi: 10.1016/j.jmig.2014.04.014

31 Chichareon SB, Wattanakitkrailert S. Endometriosis with ascites. Acta Obstet Gynecol Scand 1988;67(02):187-188. Doi: 10.3109/ 00016348809004198

32 Jose R, George SS, Seshadri L. Massive ascites associated with endometriosis. Int J Gynaecol Obstet 1994;44(03):287-288. Doi: 10.1016/0020-7292(94)90185-6

33 Myers TJ, Arena B, Granai CO. Pelvic endometriosis mimicking advanced ovarian cancer: presentation with pleural effusion, ascites, and elevated serum CA 125 level. Am J Obstet Gynecol 1995;173(3 Pt 1):966-967

34 Jeanes AC, Murray D, Davidson B, Hamilton M, Watkinson AF. Case report: hepatic and retro-peritoneal endometriosis presenting as obstructive jaundice with ascites: a case report and review of the literature. Clin Radiol 2002;57(03):226-229. Doi: 10.1053/ crad.2001.0667

35 Zeppa P, Vetrani A, Cozzolino I, Palombini L. Endometrial glands in ascites secondary to endometriosis. Diagn Cytopathol 2004;30 (02):131-132. Doi: 10.1002/dc.10390

36 Ferrero S, Remorgida V. Endometriosis presenting with hemorrhagic ascites. Arch Gynecol Obstet 2011;283(06):1429-1430. Doi: $10.1007 / \mathrm{s} 00404-010-1796-3$

37 Lin JN, Lin HL, Huang CK, et al. Endometriosis presenting as bloody ascites and shock.J Emerg Med 2010;38(01):30-32. Doi: 10.1016/ j.jemermed.2008.03.031 
38 Sait KH. Massive ascites as a presentation in a young woman with endometriosis: a case report. Fertil Steril 2008;90(05):2015.e17-2015.e19

39 Park BJ, Kim TE, Kim YW. Massive peritoneal fluid and markedly elevated serum CA125 and CA19-9 levels associated with an ovarian endometrioma. J Obstet Gynaecol Res 2009;35(05): 935-939. Doi: 10.1111/j.1447-0756.2009.01122.x

40 Hasdemir PS, Ikiz N, Ozcakir HT, Kara E, Guvenal T. Endometriosis associated with relapsing ascites and pleural effusions. J Obstet Gynaecol 2015;35(04):419. Doi: 10.3109/01443615.2014.948823

41 Cosma S, Ceccaroni M, Benedetto C. A pseudoneoplastic finding of deep endometriosis: laparoscopic triple segmental bowel resection. Wideochir Inne Tech Malo Inwazyjne 2014;9(03):463-467. Doi: 10.5114/wiitm.2014.41617

42 Hinduja I, Kapadia K, Udwadia F, Bhilawadikar R, Adhe A, Zaveri K. Unusual presentation of endometriosis with haemorrhagic ascites - A case report. J Obstet Gynaecol 2016;36(01):133-134. Doi: $10.3109 / 01443615.2015 .1030605$
43 Streuli I, Gaitzsch H, Wenger JM, Petignat P. Endometriosis after menopause: physiopathology and management of an uncommon condition. Climacteric 2017;20(02):138-143. Doi: 10.1080/ 13697137.2017.1284781

44 Meigs JV, Armstrong SH, Hamilton HH. A further contribution to the syndrome of fibroma of the ovary with fluid in the abdomen and chest, Meigs' syndrome. Am J Obstet Gynecol 1943;46:19-37. Doi: 10.1016/S0002-9378(16)40440-0

45 Bernstein JS, Perlow V, Brenner JJ. Massive ascites due to endometriosis. Am J Dig Dis 1961;6:1-6. Doi: 10.1007/BF02239240

46 Sherer DM, Eliakim R, Abulafia O. The role of angiogenesis in the accumulation of peritoneal fluid in benign conditions and the development of malignant ascites in the female. Gynecol Obstet Invest 2000;50(04):217-224. Doi: 10.1159/00001032

47 Ussia A, Betsas G, Corona R, De Cicco C, Koninckx PR. Pathophysiology of cyclic hemorrhagic ascites and endometriosis. J Minim Invasive Gynecol 2008;15(06):677-681. Doi: 10.1016/j. jmig.2008.08.012 